\title{
THE DEVELOPMENT OF COMPUTER-BASED ISLAMIC RELIGIOUS EDUCATION MODULE IN CLASS XI STUDENTS
}

\author{
Sulaiman ${ }^{1}$, Syntia Adrian Putri ${ }^{2}$ \\ Faculty of Social Sciences, Padang State University, Padang ${ }^{12}$ \\ sulaimanarrasyid@gmail.com,syntiaadrian46@yahoo.com
}

Accepted: 16-10-2021

\begin{abstract}
This article aims to produce a computer-based Islamic Religious Education module that meets the aspects of validity, practicality and effectiveness. The method used in this research is research and development with a design developed by Thiangarajan 4-D models. The research is divided into 4 stages, namely the definition stage, the design stage, the development stage and the dissemination stage.Data sources consisted of qualitative data and quantitative data. Qualitative data in the form of data was obtained through observation and interviews which include comments, criticism, and suggestions. Quantitative data in the form of analysis was collected through the results of student response from questionnaires, practicality questionnaires, validation sheets and learning outcomes tests. The subjects of this research were 32 students of class XI of MIPA at SMAN 1 Sawablunto.The data were collected throughquestionnaires, observations and tests. The results of the article showed that the computer-based IRE module met the aspects of validity, practicality, and effectiveness where $85 \%$ of student learning outcomes tests scored above 75 or in the complete category. Furthermore, the results of this study are expected to be a consideration for the next research on the development of IRE module with a wider scope for better learning and obtaining learning resources or comprehensive.
\end{abstract}

Keywords: Modules, Computer media, Islamic Religious Education.

\section{Abstrak}

Artikel ini bertujuan untuk menghasilkan modul Pendidikan Agama Islam berbasis komputer yang memenuhi aspek kevalidan, kepraktisan dan keefektifan. Metode yang digunakan dalam artikel ini adalah penelitian dan pengembangan dengan desain pengembangan oleh Thiangarajan 4-D models. Penelitian terbagi menjadi 4 tahapan yakni tahap definisi (define), tahap desain (design), tahap pengembangan (develop) dan tahap penyebaran (dessiminate). Sumber data terdiri dari data kualitatif dan data kuantitatif. Data kualitatif berupa data yang didapatkan melalui observasi serta wawancara yang meliputi masukan, komentar, kritik, dan saran. Data kuantitatif berupa evaluasi modul yang dikumpulkan melalui instrumen lembar validitas, angket praktikalitas, angket respon siswa, serta tes hasil belajar. Subjek uji coba lapangan sebanyak 32 orang siswa kelas XI MIPA SMAN 1 Sawahlunto. Teknik pengumpulan data menggunakan teknik angket, observasi dan tes. Hasil artikel menunjukkan bahwa modul PAI berbasis komputer memenuhi aspek kevalidan, kepraktisan, serta keefektifan dimana 85\% tes hasil belajar siswa memperoleh nilai di atas 75 atau dalam kategori tuntas. Selanjutnya hasil penelitian ini diharapkan dapat menjadi pertimbangan untuk penelitian pengembangan modul PAI berikutnya dengan scope dan cakupan yang lebih luas untuk pembelajaran serta memperoleh sumber belajar yang lebih baik atau komprehensif.

Kata Kunci :Modul, Media komputer, Pendidikan Agama Islam 


\section{INTRODUCTION}

Islamic Religious Education (IRE) is a learning system about Islam. Islamic religious education in schools has the aim to increase faith, knowledge, and understanding of students about Islamic teachings. It is hoped that when students have finished their education, students can understand and practice Islamic teaching in life ${ }^{1}$.Islamic Religious Education also aims to produce students who believe in Allah, are pious, and have good personalities in family, social, nation-state life, and continue the education to a higher level. ${ }^{2}$.

Education continues to develop. This requires educators, especially Islamic Education (IRE) teachers to be able to create interesting learning in order to achieve learning objectives. This is in line with Law number 20 article 40 section 2 in 2003 about the national education system, "teacher and education staff have an obligation to create meaningful, pleasure, creative, dynamic and dialogic educational atmosphere ${ }^{\prime \prime 3}$. However, the fact is that there are still many IRE teachers who have not implemented interesting learning in order to increase students' interest in learning. IRE teachers tend to apply the lecture method and use printed books that have been facilitated by the school as a source of learning material ${ }^{4}$.

This fact is in line with the author's interview at SMAN 1 Sawahlunto (20 August 2020) with a teacher who teaches Islamic Religious Education (IRE), namely Mrs. Amdawirni, S.Ag, about how the learning process and the students' interest in learning is. She explained that the learning process tends to be done by using the group discussion method, where students tend to use printed books provided by the school as teaching material. The lecture method is also implemented by educators at the end of learning process to re-explain the material that has been discussed together. The results of the interview also showed that students' interest in IRE learning was quite good, but sometimes students felt bored and needed more interesting learning media. From the results of the interview, it can be seen that the importance of choosing the right media and teaching material in an effort to increase the students' interest in learning process.

The importance of choosing media is in line with the current implementation of learning which focus on active learning and skill in the process ${ }^{5}$. The choice of the right media can make the educators to deliver learning materials easily. Therefore, teachers as educators are required to choose the right learning media in delivering the learning materials.

The development of learning media is one of the ways that can be implemented by educatorsin increasing the students'interest in learning. One of the types of media that can be developed is the learning module. Module is a learning format that is created in a systematic,

\footnotetext{
${ }^{1}$ Zakiah Drajat, Metodik Khusus Pengajaran Agama Islam (Jakarta: P.T Bumi aksara, 2008).

2 Rahmayulis, Ilmu Pendidikan Islam (Jakarta: Kalam mulia, 2010).

${ }^{3}$ Indonesia, Undang-undang Sistem Pendidikan Nasional (Jakarta: Sinar grafika, 1994).

4 Sri Wahyuni dan Sanchita Bhattacharya, "Strategy of Islamic Religious Education Teachers in Increasing Student Learning Motivation," Tafkir: Interdisciplinary Journal of Islamic Education 2, no. 2 (2 September 2021): 229-49, https://doi.org/10.31538/tijie.v2i2.22; Munaya Ulil Ilmi dkk., "The Basic Concepts of Evaluation and Its Implementation in IRE Lessons in The Pandemic Era," Tafkir: Interdisciplinary Journal of Islamic Education 2, no. 2 (30 Juli 2021): 175-90, https://doi.org/10.31538/tijie.v2i2.50; Ayse Demirel Ucan dan Andrew Wright, "Improving the Pedagogy of Islamic Religious Education through an Application of Critical Religious Education, Variation Theory and the Learning Study Model," British Journal of Religious Education 41, no. 2 (3 April 2019): 202-17, https://doi.org/10.1080/01416200.2018.1484695.

5 Tejo Nurseto, "Membuat Media yang Menarik," Jurnal Ekonomi dan Pendidikan 8, no. 1 (2011): 20.
} 
complete way, which contains learning experiences to help students in achieving certain learning objectives ${ }^{6}$.Module is also a kind of learning material that is used by students in learning independently with a little guidance from the teacher or other people ${ }^{7}$.

The module at least contains learning achievement, learning substance and assessment. Modules are basically independent learning tools, which students can be used by the students to learn independently at their own ability. This is because basically the module is a complete and systematic teaching material created for independent learning activities. Learning modules can present information in various forms of media formats. The format of the modulthat can be developed into the form of printed, video, soft files, or a combination of several formats that can be used by students or educators ${ }^{8}$.

The development of technology, especially computerization at this time is widely used in helping the world of education. Computerization in the field of education is called as Computer-Assisted Instruction (CAI), or Computer-Assisted Learning (CAL) ${ }^{9}$. The learning assistant by using the computer plays a major role in data processing ${ }^{10}$. The data that is processed using the computer becomes easier, more precise, and efficient. In the view of the presentation of computer-based learning content, CAI can be used in the form of tutors, exercises, games and simulations. Therefore, the computer in learning is a tool that helps and facilitates the learning process ${ }^{11}$.

Computer is usedas a tool to supportlearning process, one of whichis a computer-based learning module. Computer-based modules are an attractive option compared to printed modules. The computer plays a role in presenting the content of learning materials and exercises in learning. In the module, computers are also used as a tool of learning and processing data in the form of writing, visuals, audio, audio visuals, and animations. The features in computer-based modules can support abilities and increase the interest of students in learning process. Computer-based modules are also expected to make the educators to deliver material easily and to encourage students to explore wider knowledge with the features in it.

The results of the author's observations at SMAN 1 Sawahlunto also showed that the school has used computer as a media in several learning subjects that have been implemented by educators in learning process, but the use of computer-based learning modules has never been used, so it is necessary to develop media in the form of computer-based modules to increase students' interest towards IRE learning at the school.

Based on the explanation above, the problem is that the media development in learning process at SMAN 1 Sawahluntohas not been maximized, resulting in a lack of student attention in learning process. From the problems above, there are several questions as follow:

\footnotetext{
${ }^{6}$ Daryanto, Inovasi Pembelajaran Efektif (Bandung: Yrma Widya, 2013).

${ }^{7}$ Yudhi Munadi, Media Pembelajaran (Sebuah pendekatan baru) (Jakarta: Referensi, 2013).

${ }^{8}$ Liandiani, "Pengembangan Sumber Belajar" (2008).

9 Arsyad Azhar, Media Pebelajaran (Jakarta: PT Raja Grafindo Persada, 2011).

${ }_{10}$ Hamzah B Uno dan Nina Lamatenggo, Teknologi Komunikasi dan Informasi Pembelajaran (Jakarta: P.T Bumi aksara, 2011).

11 Kuncahyono Kuncahyono, "Analisis Penerapan Media Berbasis Komputer Pada Pembelajaran Tematik Terpadu di Sekolah Dasar," Jurnal Pemikiran dan Pengembangan Sekolah Dasar (JP2SD) 5, no. 2 (26 September 2017): 773, https://doi.org/10.22219/jp2sd.vol5.no2.773-780.
} 
how is the development of computer-based IRE module at SMAN 1 Sawahlunto in grade XI? How is the validity, practicality and effectiveness of the development of the computer-based IRE Module at SMAN 1 Sawahlunto in grade XI? From these questions, it is perceived important to conduct a research with the title "The Development of Islamic Religious Education (IRE) Modules for XI grade students of SMA Negeri 1 Sawahlunto".

\section{METHOD}

The type of this research is research and development (R\&D). The purpose of this research is to create a product by examining certain theories. The product developed is a computer-based learning media in the form of an Islamic Religious Education module in XI grade at SMAN 1 Sawahlunto.

The development design in this research is 4-D Models. The design of the 4-D model device development was suggested by SivasailamThiagarajan, Dorothy S. Semmel, and Melvyn I. Semmel in 1974. The 4-D design has 4 stages of development, namely: define; design; develop; and desseminate ${ }^{12}$. The 4-D design was chosen because it is more suitable, and it is better for the result of the module.

The stages of research according to the 4-D model (Thiagarajan, 1974) can be seen in Figure 1 below:

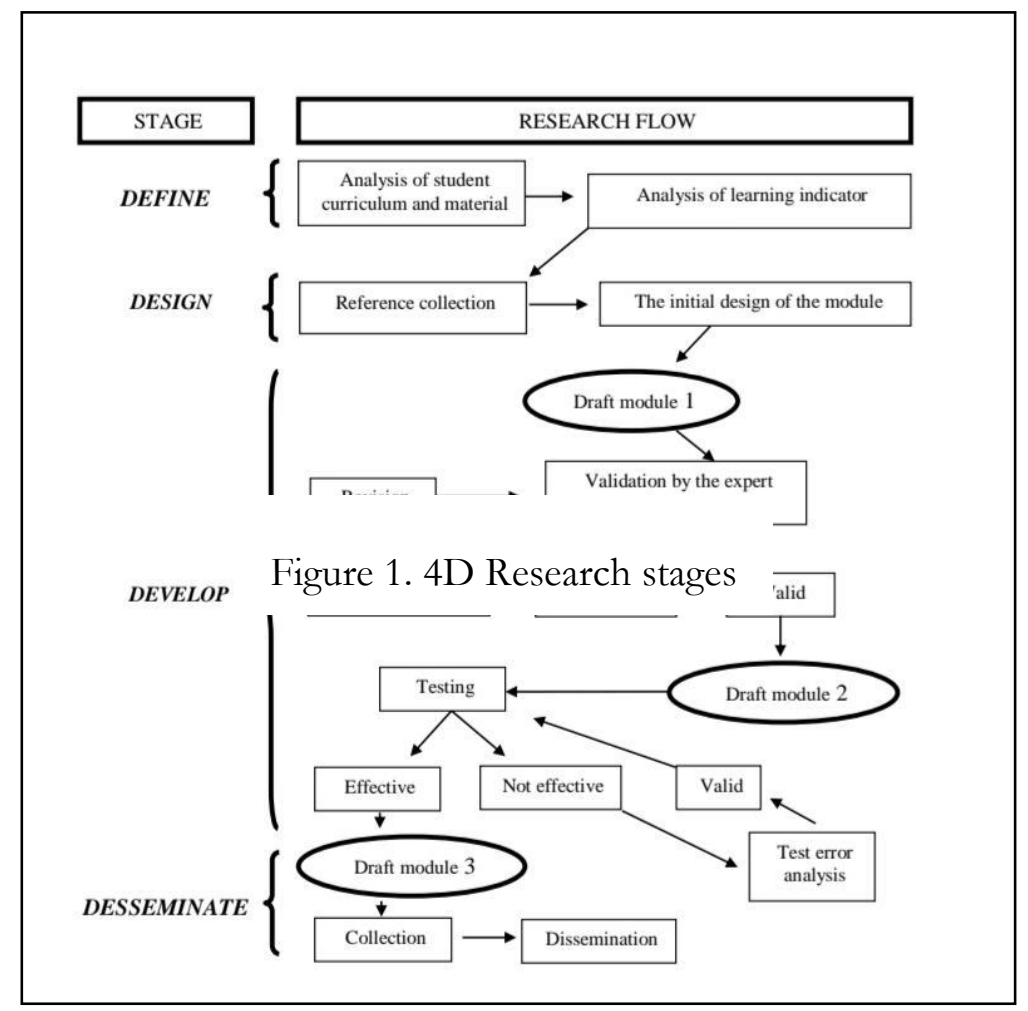

The testing of the computer-based IRE module product in this article was carried out at SMAN 1 Sawahlunto, located on Jln. Jendral Sudirman No. 7,Kelurahan Kubang Sirakuk Selatan, Kecamatan Lembah Segar, Kota Sawahlunto. The data generated from the test

12 Thiagarajan, Sivasailam, dan Dkk, Instructional Development for Training Teachers of Exceptional Children (Washinton DC: National Center for Improvement Educational System, 1974). 
appeared in the form of an evaluation of the product being tested, consisting of qualitative data and quantitative data. Qualitative data in the form of data was obtained through observation and interviews which include comments, criticism, and suggestions. Quantitative data in the form of analysis was collected through the results of student response from questionnaires, practicality questionnaires, validation sheets and learning outcomes tests.

The instruments used in this article were validation sheets, computer-based module practicality questionnaires, student response questionnaires, and learning outcomes tests. Validation sheets are used to obtain data in the evaluation of modules which is developed by experts, and the results of these evaluations were used as the basis for improving each computer-based learning module, then testing was carried out. The computer-based module practicality sheet is used to obtain data on the usefulness of the computer-based module. The results from observation sheet were then analyzed whether the module needed improvement or not. The Student Response Questionnaire is used to find out the responses from the users (students) to this module. Student Learning Outcomes Test aims to assess how the students' IRE learning outcomes on the "Islamic Reform" material after using the module.

After the instruments have been collected, an analysis was carried out in order to explain the validity, practicality and effectiveness of the computer-based module. In the process of validating data analysis, thereare several activities: (1) Recapping the results of the expert assessment into a table consisting of: Aspects $\left(A_{i}\right)$, criteria $\left(K_{i}\right)$, and assessment result $\left(V_{i j}\right)$. (2) Determining the average assessment of all validators on each criterion using the formula: $\bar{K}_{l}=\frac{\sum_{j=1}^{n} V_{i j}}{n}$, where: $\bar{K}_{l}=$ the average of the $i$ criteria, $V_{i j}=$ results obtained by the $i$ criteria by the $j$ evaluator and $n=$ the number of judges (Validator). (3) Determining the validity of all criteria, aspects or the total average using the validity categories in table 1 below $^{13}$ :

Tabel 1.Validity analysis interval

\begin{tabular}{cc}
\hline Interval & Category \\
\hline $4 \leq \mathbf{M} \leq 5$ & Very valid. \\
$3 \leq \mathbf{M}<4$ & Valid \\
$2 \leq \mathbf{M}<3$ & Quitevalid \\
$1 \leq \mathbf{M}<2$ & Not valid
\end{tabular}

If the average validity of all aspects is at least in the quite valid category, and the results of the validity of each aspect have a valid category, sothe module device has enough validity. However, if it does not reach these standards, modifications are needed according to the advice of experts or through a review of aspects whose values have not reached the minimum validity. After that, it is re-validated and then the analysis is carried out again.

Practical data analysis is carried out on the results of expert evaluations to show whether it is practical or not in implementing computer-based module devices. Based on the

13 Arsyad Nurdin, Model Pembelajaran Menumbuh Kembangkan Kemampuan Meta Kognitif (Makasar: Pustaka Refleksi, 2016). 
evaluation results from the expert, the percentage of practicality was calculated by using this formula :

$$
\text { Practicality result }=\frac{\text { the arrange score }}{\text { maximum score }} \times 100 \%
$$

Then, the practicality interval category was used ${ }^{14}$,as shown in table 2.

Tabel 2. Practicality test criteria

\begin{tabular}{cc}
\hline Interval & Criteria \\
\hline $\mathbf{8 0} \%-\mathbf{1 0 0} \%$ & Very practical \\
$\mathbf{6 0} \%-\mathbf{8 0} \%$ & Practical \\
$\mathbf{4 0 \% - 6 0 \%}$ & Practical enought \\
$\mathbf{2 0 \% - 4 0 \%}$ & Less practical \\
$\mathbf{0 \%} \%-\mathbf{2 0} \%$ & Not practical \\
\hline
\end{tabular}

If the result of the practical analysis have shown practical criteria or at intervals of $60 \%$ $80 \%$, so the computer-based IRE module is practical and feasible to be implemented on student.

Effectiveness analysis, student responses dataobtained by using a student response questionnaire, the stages in the analysis are: 1) Counting the number of students who answer questions positively from various aspects. The "negative" category is included criteria 1 and 2, the "neutral" category is included in criteria 3, and the "positive" category is included criteria 4 and 5. 2) Calculating the percentage of (1). (3) If the results of the analysis show the neutral category, then this issues that is related to the neutral aspect are modified as needed. If the results of the analysis show a negative response, then the modification of the equipment will be developed. The standard that does not need to be changed is that at least $80 \%$ of students give affirmative answers to $70 \%$ of the question or statement items, all relevant aspects are modified $^{15}$.

Analysis of learning outcomes test, the results of data analysis is used to determine the level of student learning mastery individually by analyzing the effectiveness of computer-based IRE module data, which can be determined by the formula: $K B=\frac{T}{T_{1}} 100 \%$, where: $\mathrm{KB}=$ Mastery learning, $\mathrm{T}=$ Total student scores, $T_{1}=$ Total score. The results of the analysis aim to achieve personal or classical learning completeness. If the minimum score of a student is 75 , then it is categorized as complete. If at least $85 \%$ of students achieve a minimum score of 75 , then learning process can be called classical completion ${ }^{16}$.Positive results on student response questionnaires and the achievement of classical completeness in student learning outcomes tests indicate that the module has met the effectiveness aspect.

${ }^{14}$ Riduwan, Skala Pengukuran V ariabel-variabel Penelitian (Bandung: Alfabetha, 2007).

15 Majid Abdul, "Pengembangan Modul Matematika pada Materi Garis dan Sudut Setting Pembelajaran Kooperatif Tipe Think Pair Share (TPS) untuk Siswa Kelas VII SMP.” (Universitas Negeri Makasar, 2014).

16 Trianto, Mendesain Model Pembelajaran Inovatif (Jakarta: Kencana Prenada Media Grup, 2010). 


\section{RESULTS AND DISCUSSION}

The define stage is the initial stage of module design which aims to analyze learning needs or requirements. This learning needs to review the ongoing curriculum, school conditions and the level of development of students. The stages in this phase are usually referred to pre-research phase which includes preliminary and final analysis, student analysis, material analysis and indicator analysis. The results of the activities at this stage can be seen as follows:

Preliminary and final analysis was used to find out the problems faced by SMAN 1 Sawahlunto teachers, especially IRE teachers who teach in XI grade. Based on the results of discussions and through learning activities with IRE teachers at SMAN 1 Sawahlunto, it was found that the implementation of IRE learning, especially XI grade at SMAN 1 Sawahlunto still focused on printed books, teaching materials, and media such as power point provided by school or teacher. Computer-based learning modules have never been developed for studentsat SMAN 1 Sawahlunto. Students' interest in IRE learning was quite good, but sometimes students felt bored and needed more interesting learning media.

The subjects in this product trial were students in class XI of SMAN 1 Sawahlunto in the 2020/2021 academic year. In the student analysis, the researcher examined the cognitive development of students according to their development and the language used by students. The majority of students use Indonesian as their daily language. From the perspective of cognitive development, students are included in the formal computing stage (11-18 years old) where students can have logical and abstract thinking and are able to draw conclusions ${ }^{17}$. In fact, students still need pictures or explanations in the form of images, sounds, and videos in Islamic Religious Education (IRE).

In material analysis, the activities are in the form of identifying, improving, and organizing in a systematic way. The subject in this module was the material about"Islamic Reform" based on the Curriculum 2013 content standards. The outline of the material based on the achievement indicators includes the understanding the stages of Islamic culture and history, the influence of modern Islamic reformers and the influence of the revival movement on the development of Islam in Indonesia.

In indicator analysis, this step is to transform the results of material analysis to achieve learning objectives. This goal becomes the basis for the preparation of testing and designing computer-based Islamic Religious Education modules.

Furthermore, the second stage, namely the design phase aims to determine a learning device which is called as a prototype or draft module. Prototype is a product design that will be created. The steps to produce a draft 1 module include collecting reference materials and the designing the initial module. At this stage, the researcher began to design a computerbased learning module which includes several aspects, namely:

The choice of format adapts to the syntax of computer-based Islamic learning, including basic competency standards, indicators, learning objectives, evaluations, learning processes and teaching material. With this syntax, it was hoped that the students' interest in

\footnotetext{
${ }^{17}$ Kokom Komalasari, Pembelajaran Konstektual dan Aplikasi (Bandung: P.T Refika Aditama, 2011).
} 
learning process will increase. This module was created without a special syntax so that teachers could choose their own models, approaches, and methods in learning which are right for students. The choice of format should be colorful, organized, neat, and structured so that students will be interested, motivated, and facilitate learning.

In the initial design of the module, the researcher collected information on how to make a cover of the module from various sources. It was started from the examples of book cover and other example of covers from the existing modules so that researchers could createbetter designs through combination of several types of colors and some appropriate pictures so that students were interested in exploring the contents of the module by looking at the cover of the module.

Figure 2. Cover

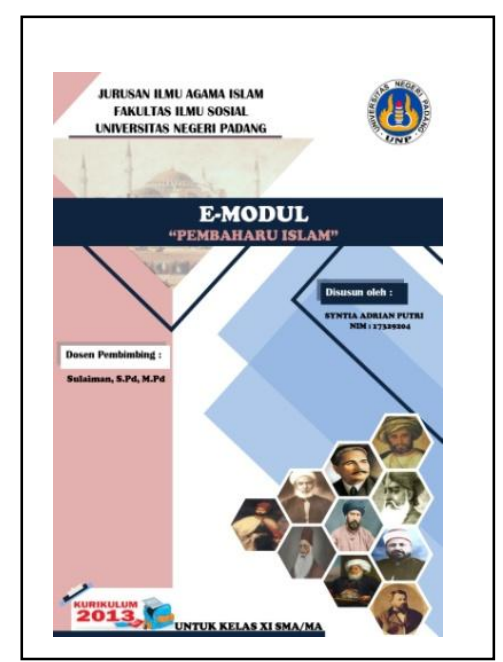

Figure 3. Content

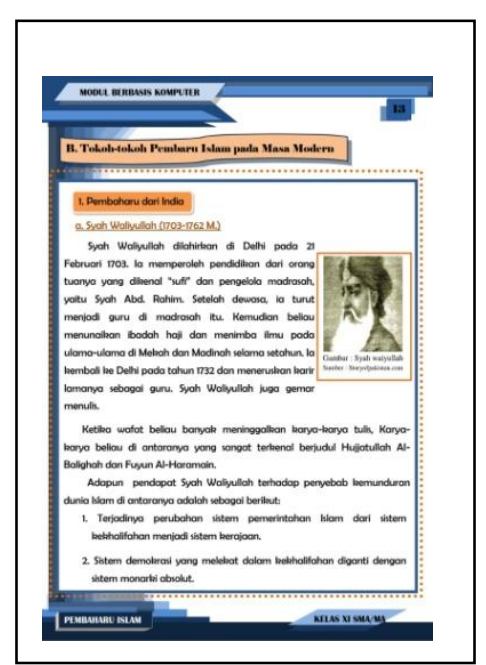

The material was determined to design appropriate learning for the student in order to achieve their abilities. This design was also useful for adjusting to the requirements of basic abilities and learning objectives related to the selected material. In contrast to printed modules or regular textbooks, this module provided a variety of colors, images, understandable language, and clickable worksheet pages, in order to help the students to understand while reading and studying, as well as additional video links for material to gain more material or to strengthen the material, because modules could be constructed in order to help the students to understand the topic.

The design of the content of the module includes: 1) Title, the design of the title refers to the subject of "Islamic Reform" in class XI of high school because this module uses a computer-based learning syntax, entitled "E-module". 2) Preface or introduction, including the author's gratitude for completing the module and the benefits of the module. 3) Instructions for using the module, including instructions for using the module according to the computer-based syntax, so that the module can be accessed the same as an electronic book (e-book). Therefore, this section also show what users (students) should do when using the module. The module instructions also consist of instructions for teachers and instructions for students. 4) The table of contents introduces the themes contained in the module to the 
reader along with the page numbers. Therefore, users can easily find the theme without checking the entire content of the module.
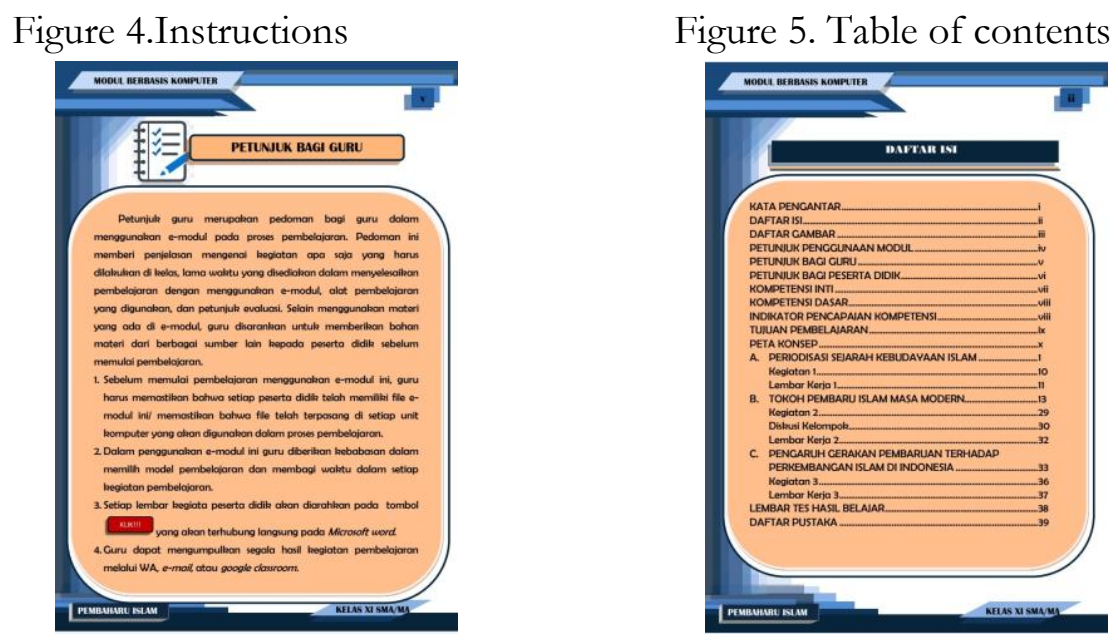

5) Basic competence, namely the achievement of the reader after the learning activities are completed. 6) Ability achievement indicators, consisting important instructions about competencies that must be achieved after the learning process. 7) Mind mappping, consistingimportant information about the relationship between materials, in order to help the users (students) to understand the material as a whole. 8) Main material, containing some of the main material to be learned. 9) Description of the material, containing more detailed learning materials. The material description also contains student activities with computerbased learning syntax. Therefore, the reader can understand deeply. 10) Activities and worksheets, provided at the end of each discussion or at the end of each learning activity. It consists of the attitude assessments and assessments in the form of questions related to the useful material to see how well students (readers) master the material in each learning process. This module also contains discussion sheets or group discussion activities in order to help the students to do independent learning in groups with the guidelines and worksheets that have been provided. 11) Learning Outcome Test, this test is at the end of the lesson to measure how well the students (users) have learned the series of materials in the module.

Figure 6. Discussion activity

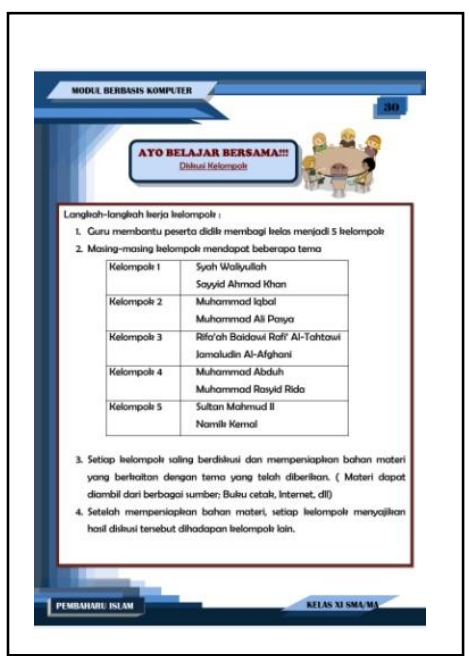

Figure 7. Learning outcomes

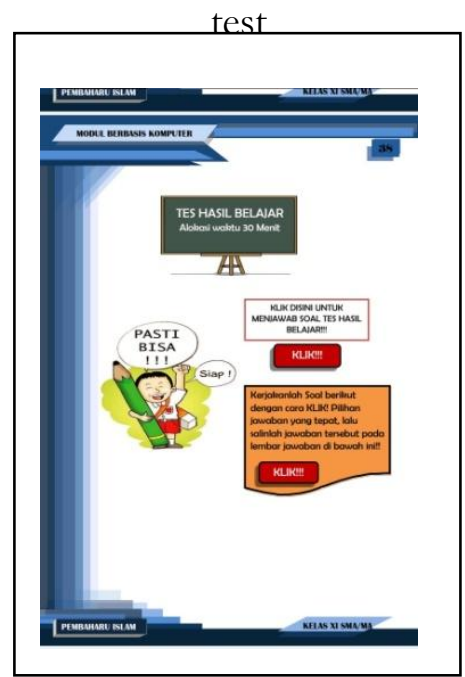


12) Summary, containing a summary of the material at the end of the lesson. 13) Bibliography, containing reference materials. Therefore, if a student wants to understand deeply or want to learn more about the problem from the reference, then it can be traced back.

Furthermore, the third stage in this research is the develop phase which aims to create learning tools that have been improved and tested by experts and IRE teachers. This stage includeddevice verification by expert lecturers and IRE teachers. If there were deficiency found in the product, it was continued with revision. The revision became a draft of Module 2. The draft of Module 2 was read by students for a readability test, then modified and analyzed. This stage aims to see the results of the analysis of the validity, practicality and effectiveness of the computer-based module as follows:

The results of the validity test aim to obtain data about the validity of the module by using a validation sheet instrument. There were some lecturers from UniversitasNegeriwho were selected as a team of experts or validators, namely Dr. Indah Muliati, M.Ag and Dr. RiniRahman, M.Ag. The first thing to do in this validity test was product verification, namely product assessment by experts in the form of suggestions and comments related to products. Validation was carried out directly to the validator team to evaluate and verify the product by demonstrating the product. The verification process was carried out first by submitting the initial design of the computer-based module to the validator team that was developed at the beginning. After the product revision was carried out according to the suggestions of the two experts in the first verification, it was continued into the second product verification. After the second product verification, a product revision was carried out until there were no more suggestions and comments from the validator.

Furthermore, the validity test was done by the validator. There were some aspects that were tested by the validator including aspects of graphic feasibility, language aspects, content, presentation, and aspects of computer information technology. Through the assessment by the validator team, it was hoped that the quality of the product could be tested theoretically as well as attractive in appearance. After the validity test was carried out by the validator team, then the results were analyzed and the results showed that the computer-based Islamic Religious Education module received result of 4.43. These results referred to the "very valid" category, which was in the interval $4 \leq \mathrm{M} \leq 5$.

After modifying the first module draft based on the validation results, the second module draft was obtained. This Module II draft was tested by students in class XI of MIPA 1 at SMAN 1 Sawahlunto in the second semester of the 2020/2021 academic year. The 32 students have different academic abilities. The team of observers in this module testing was the IRE teacher for class XI, Mrs. Amdawirni, S.Ag.

The practicality test was carried out by using a practicality questionnaire instrument which consists of convenience aspects of the use of e-modules, time efficiency and the benefits of e-modules in learning process. The results of the practicality test of the computerbased IRE module were obtained from Mrs. Amdawirni, S.Ag as an observer during the learning process. After the testing through the practicality sheet was analyzed, the results showed that the percentage of practicality result $98 \%$ which indicated the category "Very 
practical" so that the computer-based IRE module did not need to be revised and has met the practicality criteria.

Analysis of student responses to the computer-based IRE module was carried out by analyzing data from the results of the computer-based module testing in class XI MIPA-1 with 32 students. At this stage, students learned by using e-modules. Then theeffectiveness testof e-modules was carried out by using a student response questionnaire instrument. The 32 student responses were analyzed and concluded that more than $80 \%$ of students gave positive responses.

In the analysis of student learning outcomes tests, all student learning outcomes were analyzed and concluded that 28 of 32 students or more than $85 \%$ of students got the score above 75 and included in the "Completed" category. Based on the results of the analysis of student response questionnaires and student learning outcomes tests, it can be concluded that the computer-based IRE module met the criteria of effectiveness.

The last stage of module development by using 4-D models is the desseminate phase. This last stage was carried out in a limited and simple way through socialization to SMAN 1 Sawahlunto teachers, especially IRE teachers in class XI. The process of socialization was in the form of providing soft files to IRE teachers and distributing modules on several computers in the language laboratory of SMAN 1 Sawahlunto. Next, the researcher explained the existing details and how to use the module to the IRE teacher for class XI that is Mrs. Amdawirni, S.Ag. At this stage, Mrs. Amdawirni, S.Ag did not give much advice, she only asked about the content and how to use the module. The suggestion from her was about the content of the module in the form of material that must be suitable with the learning objectives.

\section{CONCLUSION}

The product in this article is a computer-based IRE module that met the aspects of validity, practicality and effectiveness through the stages of research and development. After the implementation of the research, it can be concluded that:

The stages in the research and development of this computer-based module use a 4-D model with 4 stages, namely the define stage, design stage, developp stage, and the dissemination stage.

The results of the analysis of the research and development of the computer-based Islamic Religious Education module in class XI of SMAN 1 Sawahlunto showed that the module is included in the valid, practical and effective category. (a) The module included all of its contents category as meeting the validity aspect because it gets the testing result of 4.43 which refers to the "very valid" category which is in the $4 \leq \mathrm{M} \leq 5$ interval., (b) The module included all its contents which are categorized as practical based on the results of observational analysis carried out by experts where the computer-based Islamic Religious Education module device obtains the percentage of practicality result $98 \%$, this figure indicated the category "Very practical" which is included in the interval category $80 \%-100 \%$, and (c) The module covered all its contents effectively because it has met the two criteria as references where more than $80 \%$ of students gave positive responses to the module and more than $85 \%$ of students get the score above 75 or were included in the "Completed" category after using the computer-based IRE module. 


\section{REFERENCES}

Abdul, Majid. "Pengembangan Modul Matematika pada Materi Garis dan Sudut Setting Pembelajaran Kooperatif Tipe Think Pair Share (TPS) untuk Siswa Kelas VII SMP." Universitas Negeri Makasar, 2014.

Azhar, Arsyad. Media Pebelajaran. Jakarta: PT Raja Grafindo Persada, 2011.

Daryanto. Inovasi Pembelajaran Efektif. Bandung: Yrma Widya, 2013.

Demirel Ucan, Ayse, dan Andrew Wright. "Improving the Pedagogy of Islamic Religious Education through an Application of Critical Religious Education, Variation Theory and the Learning Study Model." British Journal of Religious Education 41, no. 2 (3 April 2019): 202-17. https://doi.org/10.1080/01416200.2018.1484695.

Drajat, Zakiah. Metodik Khusus Pengajaran Agama Islam. Jakarta: P.T Bumi aksara, 2008.

Ilmi, Munaya Ulil, Farid Setiawan, Maulida Nurul Hikmah, Arrum Kharisma, Dimas Feryawan, dan Aiman Affan Hanafie. "The Basic Concepts of Evaluation and Its Implementation in IRE Lessons in The Pandemic Era." Tafkir: Interdisciplinary Journal of Islamic Education 2, no. 2 (30 Juli 2021): 175-90. https://doi.org/10.31538/tijie.v2i2.50. Indonesia. Undang-undang Sistem Pendidikan Nasional. Jakarta: Sinar grafika, 1994.

Komalasari, Kokom. Pembelajaran Konstektual dan Aplikasi. Bandung: P.T Refika Aditama, 2011.

Kuncahyono, Kuncahyono. "Analisis Penerapan Media Berbasis Komputer Pada Pembelajaran Tematik Terpadu di Sekolah Dasar." Jurnal Pemikiran dan Pengembangan

Sekolah Dasar (JP2SD) 5, no. 2 (26 September 2017): 773. https://doi.org/10.22219/jp2sd.vol5.no2.773-780.

Liandiani. "Pengembangan Sumber Belajar," 2008.

Munadi, Yudhi. Media Pembelajaran (Sebuah pendekatan baru). Jakarta: Referensi, 2013.

Nurdin, Arsyad. Model Pembelajaran Menumbuh Kembangkan Kemampuan Meta Kognitif. Makasar: Pustaka Refleksi, 2016.

Nurseto, Tejo. "Membuat Media yang Menarik." Jurnal Ekonomi dan Pendidikan 8, no. 1 (2011): 20.

Rahmayulis. Ilmu Pendidikan Islam. Jakarta: Kalam mulia, 2010.

Riduwan. Skala Pengukuran Variabel-variabel Penelitian. Bandung: Alfabetha, 2007.

Thiagarajan, Sivasailam, dan Dkk. Instructional Development for Training Teachers of Exceptional Children. Washinton DC: National Center for Improvement Educational System, 1974. Trianto. Mendesain Model Pembelajaran Inovatif. Jakarta: Kencana Prenada Media Grup, 2010.

Uno, Hamzah B, dan Nina Lamatenggo. Teknologi Komunikasi dan Informasi Pembelajaran. Jakarta: P.T Bumi aksara, 2011.

Wahyuni, Sri, dan Sanchita Bhattacharya. "Strategy of Islamic Religious Education Teachers in Increasing Student Learning Motivation." Tafkir: Interdisciplinary Journal of Islamic Education 2, no. 2 (2 September 2021): 229-49. https://doi.org/10.31538/tijie.v2i2.22. 